\title{
時間分解測光による鋼中 $\mathrm{C}, \mathrm{P}$ および $\mathrm{S}$ の発光分光分析
}

\section{Determination of C, P and S in Steels by Time-resolved Atomic Emission Spectrometry}

Yoshiro Matsumoto

\section{Synopsis :}

The time-resolving technique was applied to the determination of a trace amount of elements $\mathrm{C}, \mathrm{P}$ and $\mathrm{S}$ in steels.

The results were as follows :

(1) A higher precision analysis was performed. The analytical repeatabilities in standard deviations at an elemental concentration of $10 \mathrm{ppm}$ were $2.3 \mathrm{ppm}$ for $\mathrm{C}, 0.8 \mathrm{ppm}$ for $\mathrm{P}$ and $0.5 \mathrm{ppm}$ for $\mathrm{S}$.

(2) Spectral interferences were almost avoided in this case. The concentration correction factors were $0.16 \times 10^{-4}$ for an interference of $\mathrm{Ni}$ on the PI $178.29 \mathrm{~nm}$ line and $0.2 \times 10^{-4}-5.8 \times 10^{-4}$ for that of $\mathrm{Mn}$ on the SI $180.73 \mathrm{~nm}$ line.

Key words : atomic emission spectrometry ; time-resolving ; trace elements ; carbon ; phosphorus ; sulfur.

\section{1. 緒}

鋼の成分分析にはスパーク放電による発光分光分析法 が広く用いられ(1)2)，近年，この方法による C, P, S 等の微量成分の分析が重要となっている3). 微量濃度に おいては連続光がバックグラウンドとなること，分析成 分以外の含有成分の発光スペクトルが分析スペクトル線 に近接線として重なることが分析誤差の主要因の一つと なる ${ }^{4)}$. これらの影響を除き，高精度分析を行う方法と してスペクトルの時間分解測光法を挙げることができ $3^{556)}$. 時間分解測光の基本的な研究は, 鉄鋼試料への 適用7)8) も含め，これまで二，三行われているが9) 13)， 実用面での研究を行った例は少ない. 今回, 微量 C, P, $\mathrm{S}$ を高精度に分析すること，および，共存元素の発光 スペクトルが近接線として生じる重なりの影響を隇少さ せることを目的として, 時間分解測光法を適用したので, その結果を述べる.

\section{2. 実 臨 方 法}

実験には時間分解測光が可能な市販の発光分光分析装 置 $^{14)}$ を用いた．時間分解測光の回路図を Fig. 1 に，測
定条件を Table 1 に示す. 測光部の回路はPDA 測光 法 (Pulse Distribution Analysis Method) ${ }^{15) 16)}$ の回路に 時間分解測光のための積分スイッチ, サンプリングホー ルド回路およびタイミング制御回路が加わったものに なっている，一回の放電における放電開始点（時間の原 点）からの一定の経過時間（以下，この時間を設定時間 と呼ぶ）がタイミング制御回路に設定され，時間分解測 光が行われる. 放電開始点がスパーク放電源のイグナイ ターの光を検出することにより決められ, 測光のシーケ ンスはマイクロコンピューターで制御される．放電開始 とともに単一積分器で光量が積分されていく．設定され た時間に達すると積分タイミングスイッチが動作し閉に

Table 1. Analytical conditions.

\begin{tabular}{|c|c|c|}
\hline Spectrometer & $\begin{array}{l}\text { Focal length } \\
\text { Reciprocal linear dispersion }\end{array}$ & $0.46 \mathrm{~nm} / \mathrm{mm}$ \\
\hline Excitation source & $\begin{array}{l}\text { Secondary voltage } \\
\text { Spark repetition rate } \\
\text { Counter electrode } \\
\text { Ar gas flow rate } \\
\text { Ar gas flash }\end{array}$ & $\begin{array}{l}400 \mathrm{~V}_{1} \\
300 \mathrm{~s}^{-1} \\
\mathrm{Ag} \\
10 \mathrm{l} / \mathrm{min} \\
3 \mathrm{~s}\end{array}$ \\
\hline Number of discharges & $\begin{array}{l}\text { Pre-burn } \\
\text { PDA measurement }\end{array}$ & $\begin{array}{l}\text { Conbined } 2000 \text { plus } \\
\text { spark } 500 \\
\text { Spark } 1500\end{array}$ \\
\hline
\end{tabular}

昭和 61 年 10 月本会講演大会にて発表 平成元年 10 月 11 日受付 (Received Oct. 11, 1989)

* 住友金属工業(株)未来技術研究所 工博 (Advanced Technology Research Laboratory, Sumitomo Metal Industries, Ltd., 1-3 Nishinagasuhondori Amagasaki 660) 


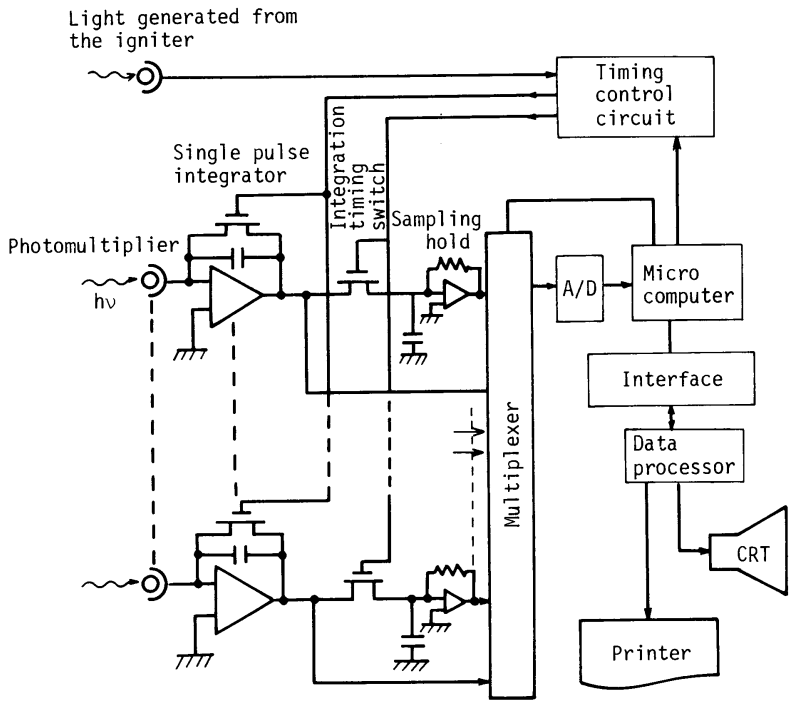

Fig. 1. Schematic diagram of timeresolving measurement system. (a) Spark discharge (b) Combined discharge
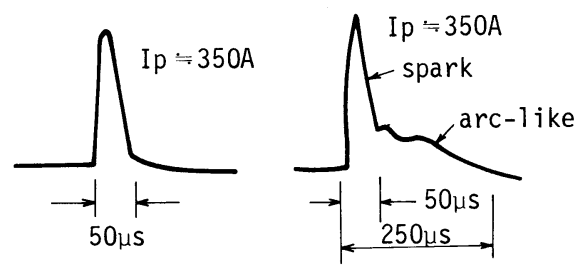

Fig. 2. Schematic diagram of current waveforms of spark and combined type discharges.

なり設定時間までの光量がサンプリングホールド回路に 記憶される。一放電の全光量は単一積分器に積分される. (i)放電開始から設定時間までの積分值，（ii）一放電の全 積分值は A/D 変換されマイクロコンピューターのメモ リーに入力され, 単一積分器およびサンプリングホール ド回路の電荷は放電される. 出力としては一スパーク放 電における $(\mathrm{i})$ 全強度，（ii)放電開始から設定時間までの 強度，（iii)設定時間以降の全強度，についての測定值が 得られる. 実験では $0,5,10,15,20,30,40,50$, $60 \mu \mathrm{s}$ の設定時間以降の全強度のデー夕を用いた。なお， $0 \mu \mathrm{s}$ は時間分解測光を行わないことを表す.

放電には Fig. 2 のスパーク放電およびスパーク放電 とアークライク放電を組み合わせたコンバインド放 電 ${ }^{14)}$ を用いた。コンバインド放電は予備放電に用い, スパーク放電による発光において，スペクトル線強度の 測光を行った. コンバインド放電による予備放電パルス 数は時間分解測光を行わない条件で, C の発光強度と
放電パルス数の関係を調へ， 発光強度が安定するまでの 2000 パルスとした.コンバインド放電に続いてスパー ク放電により 2000 パルス放電し, 最初の 500 パルス を予備放電として用い, 残りの 1500 パルスにおいて測 光した.この実験での測定はパルス分布の中央值 ${ }^{16)}$ 測定強度とした. 分析線 ${ }^{17)}$ には一般的な CI $193.09 \mathrm{~nm}$, PI $178.29 \mathrm{~nm}$ および SI $180.73 \mathrm{~nm}$ を用いた. Fe の 分析線 FeI $287.23 \mathrm{~nm}^{17)}$ をパルス分布測定でのディス クリミネーター16)に用いた。また，時間分解測光の効 果を考察するには $\mathrm{Fe}$ の分析線との強度比をとらずに分 析線の強度のみを扱う方が容易であり，かつ内標準を とった場合ととらない場合で同等の分析精度が得られた ので，本実験では内標準をとらない強度を測定強度とし て用いた。

\section{3. 実験結果および考察}

\section{$3 \cdot 1$ 感度, バックグラウンドおよび精度}

スペクトルのプロフィール, 感度, バックグラウンド 強度, BEC (Background Equivalent Concentration) お よび分析精度を調べた．実験には，Table 2 の真空溶解， 鍛伸により作製した $\mathrm{C}=10 \sim 100 \mathrm{ppm}, \mathrm{P}=1 \sim 82 \mathrm{ppm}$, $\mathrm{S}=4 \sim 88 \mathrm{ppm}$ の濃度範用の 7 種類の試料を用いた.

(1) スペクトルのプロフィール

$\mathrm{C}, \mathrm{P}$ および $\mathrm{S}$ の時間分解スペクトルを Fig. 3 に示 すＣでは濃度 $100 \mathrm{ppm}$ の試料を用いた．時間分解測 光を行わない場合には, CI $193.09 \mathrm{~nm}$ のスペクトル線 の近傍に Fe III $193.15 \mathrm{~nm}$ および FeIII $193.03 \mathrm{~nm}$ のス 
ペクトル線が強く生じている. $20 \mu \mathrm{s}$ のプロフィールで は時間分解測光を行わない時 $(0 \mu \mathrm{s})$ より全波長域で光 強度は減少しているが, 中性線 CI $193.09 \mathrm{~nm}$ の光強度 に比較し， 2 価のイオン線 Fe III $193.15 \mathrm{~nm}$ および Fe III $193.03 \mathrm{~nm}$ の光強度の滅少量は大きい。また, Fe II $193.25 \mathrm{~nm}$ のスペクトル線では自己吸収による反転が生 じている. さらに, 30,40 および $50 \mu \mathrm{s}$ でのプロフィー ルにおいても CI $193.09 \mathrm{~nm}$ に比較し, FeIII $193.15 \mathrm{~nm}$

Table 2. Reference samples used for the experiment (ppm).

\begin{tabular}{ccccccc}
\hline Sample No. & C & Si & Mn & P & S & Al \\
\hline 1 & 15 & 13 & 1900 & 1.3 & 3.7 & 38 \\
2 & 10 & 40 & 2000 & 2.2 & 4.0 & 33 \\
3 & 22 & 58 & 2000 & 1.7 & 5.2 & 34 \\
4 & 12 & 91 & 1900 & 8.7 & 9.4 & 69 \\
5 & 27 & 89 & 1900 & 18 & 20 & 61 \\
6 & 50 & 247 & 2000 & 48 & 49 & 44 \\
7 & 100 & 559 & 2000 & 82 & 88 & 67 \\
\hline
\end{tabular}

および FeIII 193.03 nm のスペクトル線強度の減少が大 きい.スパーク放電はアーク放電に比べ電流密度が高く, 従ってプラズマ温度が高い。このため, 放電の初期には 連続スペクトル（波長に対して連続）以外にマトリック ス成分である Fe のイオン線も発生し，分析線に近接し ている場合にはバックグラウンドの要因となる ${ }^{5) 6)}$. 時 間の経過とともに放電電流が減衰し，プラズマ温度が低 下し，イオン線の強度が弱くなる．実験では放電電流が なくなる $50 \mu \mathrm{s}$ においては $\mathrm{Fe}$ の近接線の強度はほとん ど消失した．これに対して，中性線である $\mathrm{C}$ の分析線 では放電電流が減衰しても，特に Ar 雲囲気中ではアフ

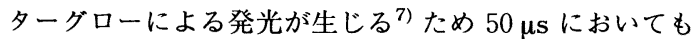
ピークが観察された。

$\mathrm{P}$ においても時間分解測光を行わない時のプロ フィールでは PI $178.29 \mathrm{~nm}$ のスペクトル線に近接線の 影響が大きく生じている．放電開始点からの時間が 10 , (a) Carbon

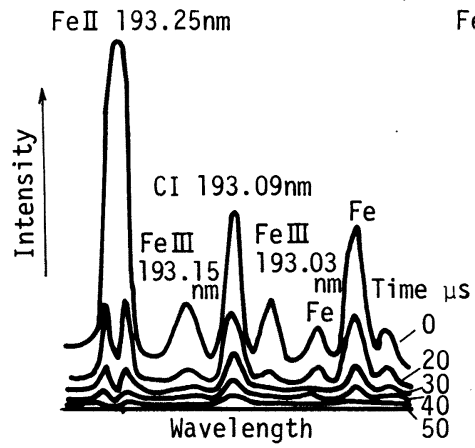

(b) Phosphorus

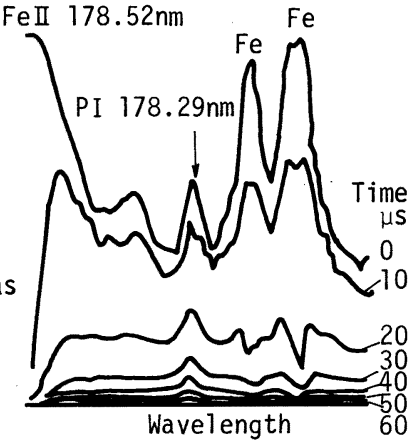

(c) Sulfur

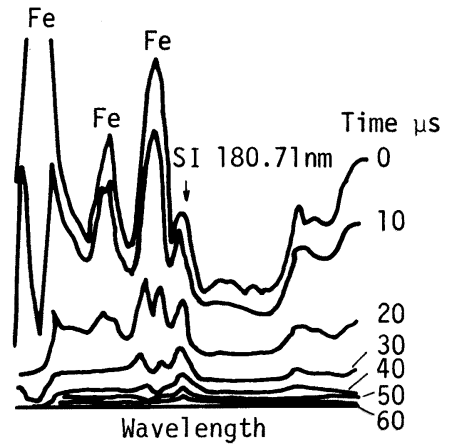

Fig. 3. Line profiles as a function of the time elapsed relative to discharge initiation in the determination of carbon, phosphorus and sulfur. Each concentration of the samples used for the experiment was : C 100 ppm, P 82 ppm, and S 88 ppm.

(a) Carbon

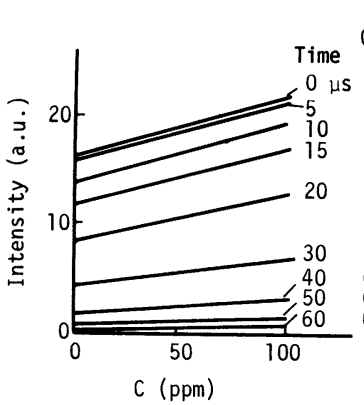

(b) Phosphorus

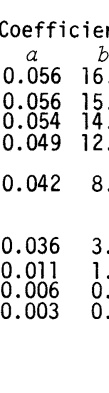
Coefficient

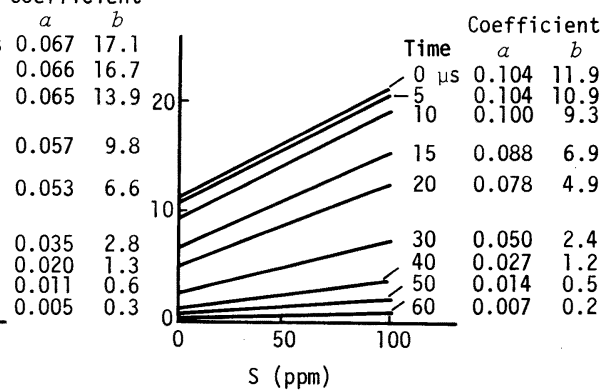

Fig. 4. Variation in shape of working curves as a function of the time elapsed relative to discharge initiation for carbon, phosphorus and sulfur. 
(a) Carbon

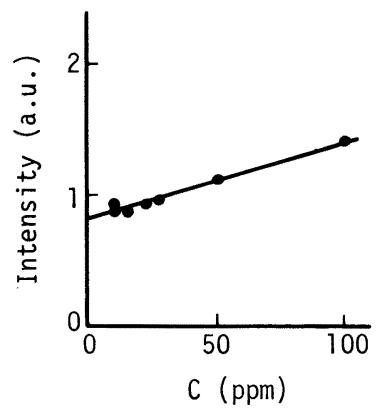

(b) Phosphorus

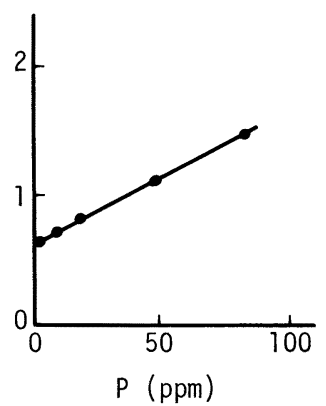

(c) Sulfur

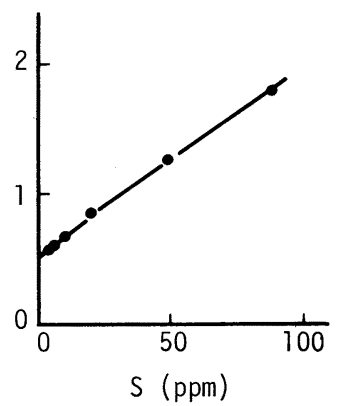

Fig. 5. Working curves at a time elapsed of $50 \mu$ s relative to discharge initiation.
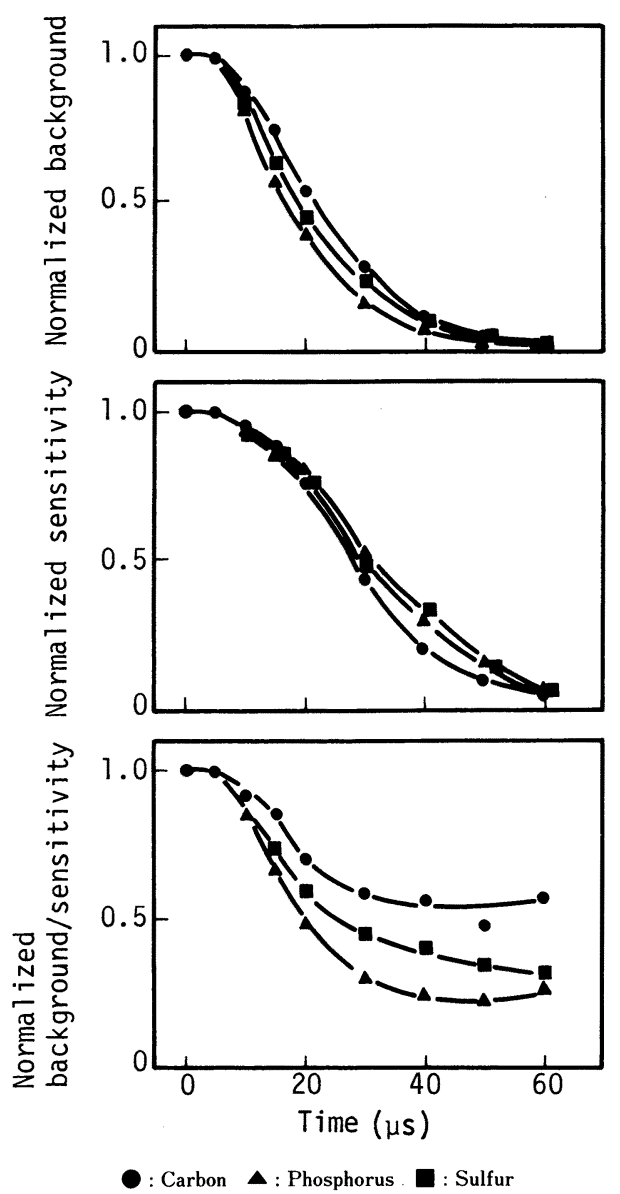

Fig. 6. Variation in background, sensitivity and background to sensitivity ratio as a function of the time elapsed relative to discharge initiation for the CI $193.09 \mathrm{~nm}$, PI $178.29 \mathrm{~nm}$ and SI $180.73 \mathrm{~nm}$ lines.
$20,30,40,50 \mu \mathrm{s}$ と増加するに従って近接線の強度は PI $178.24 \mathrm{~nm}$ のスペクトル線強度より大きく減少し, $\mathrm{P}$ のスペクトル線に対する影響は小さくなっている. 30，40，50，60 $\mu \mathrm{s}$ においては，P のスペクトル線に対 する近接線の影響はほとんど除かれている，また，SI $180.73 \mathrm{~nm}$ のスペクトル線に対する近接線の影響も時間 分解測光により減少している.

( 2 )BEC および分析精度

CI $193.09 \mathrm{~nm}$, PI $178.29 \mathrm{~nm}$, SI $180.73 \mathrm{~nm}$ のそ れぞれの分析線の光強度と試料濃度の関係について, 時 間分解の設定時間をパラメーターとして調べた. 分析試 料の測定強度 $I$ と濃度 $w$ との関係を一次回㷌式 $I=$ $a \cdot w+b(a, b$ 定数 $)$ により求めた.この結果を Fig. 4 に, $50 \mu \mathrm{s}$ の場合についてプロットしたデータの例を Fig. 5 に示す. 回帰式の傾き (感度) $a$, バックグラウ ンド強度 $b$ および $b / a$ の值をそれぞれの元素において 規格化した後, 設定時間に対してプロットした結果を Fig. 6 に示す. 時間分解の設定時間が大きくなるとバッ クグラウンド強度および傾き（感度）が小さくなる.

Fig. 6 の規格化した值を比較すると時間分解測光によ り，バックグラウンドは傾きより大きく低下するため, $b / a$ の值は 1 より小さくなっている， $b / a$ を規格化しな い值である BEC は時間分解測光を行わない時, C 286 ppm, P 255 ppm, S 107 ppm 一例として $50 \mu \mathrm{s}$ では C 139 ppm, P 59.3 ppm, S 37.4 ppm であり, Fig. 7 の ように時間分解測光により BEC は小さくなることがわ かる.

相対標準偏差 $(n=10)$ をそれぞれの設定時間につい て求め, 回帰式により濃度の関係として整理した。代表 例として時間分解測光を行わない時および $50 \mu \mathrm{s}$ での結 果を Fig. 8 に示す.これらの回㷌式から $10 \mathrm{ppm}$ の濃 度における標準偏差を求めた。時間分解測光を行わない 


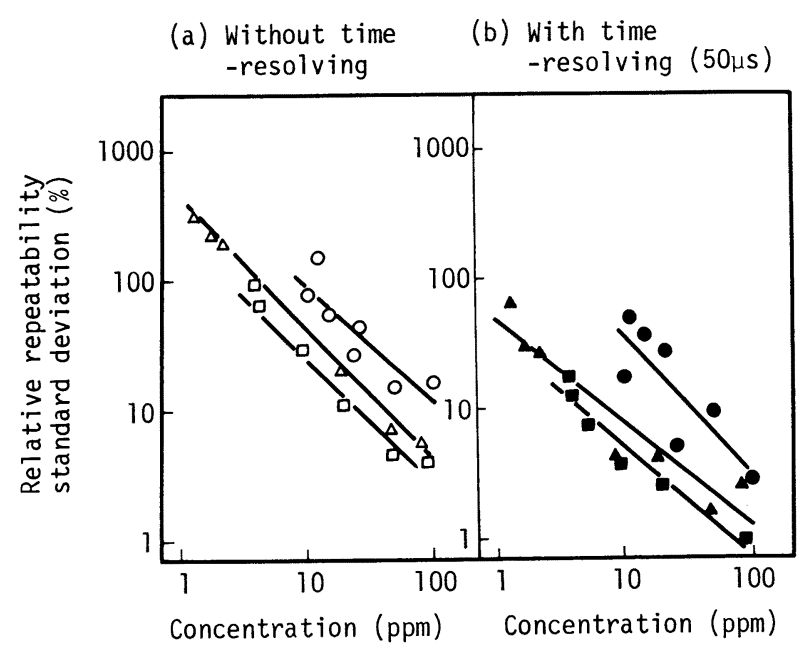

0 : Carbon $\triangle \boldsymbol{\Delta}$ : Phosphorus $\square \mathbf{0}$ : Sulfur Fig. 8. Comparison of relative standard deviation with and without timeresolving technique.

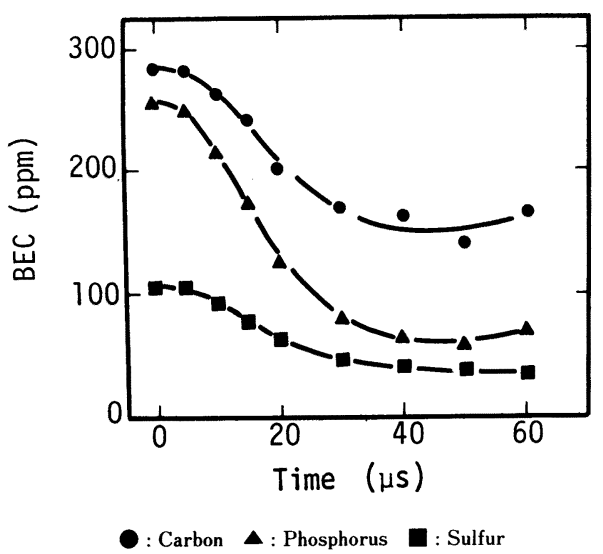

Fig. 7. Background equivalent concentration as a function of the time elapsed relative to dischage initiation for carbon, phosphorus and sulfur.

時は C $8.7 \mathrm{ppm}, \mathrm{P} 4.2 \mathrm{ppm}, \mathrm{S} 2.4 \mathrm{ppm}$ であった。時 間分解測光を行った時については精度の良かった 40 , $50,60 \mu \mathrm{s}$ の結果を示すと $40 \mu \mathrm{s}$ では C $2.3 \mathrm{ppm}, \mathrm{P} 0.8$ $\mathrm{ppm}, \mathrm{S} 0.8 \mathrm{ppm}, 50 \mu \mathrm{s}$ では C $3.7 \mathrm{ppm}, \mathrm{P} 0.8 \mathrm{ppm}$, $\mathrm{S} 0.5 \mathrm{ppm}, 60 \mu \mathrm{s}$ では C $6.8 \mathrm{ppm}, \quad \mathrm{P} 0.9 \mathrm{ppm}, \quad \mathrm{S} 0.7$ ppm であった. 本実験での最適設定時間における標準 偏差は C $2.3 \mathrm{ppm}(40 \mu \mathrm{s}), \mathrm{P} 0.8 \mathrm{ppm}(40$ および 50 $\mu \mathrm{s}), \mathrm{S} 0.5 \mathrm{ppm}(50 \mu \mathrm{s})$ であった. スパーク放電電流 は $50 \mu \mathrm{s}$ でほとんど減衰し，近接線もこの時間ではほと んど消失した.このため, $50 \mu \mathrm{s}$ 程度までは設定時間の 増加とともに分析精度は良くなった。 $60 \mu \mathrm{s}$ あるいは実 験結果は示さなかったが, さらに設定時間が増すと, 分 析線強度の低下も大きいため分析精度が劣化していく結

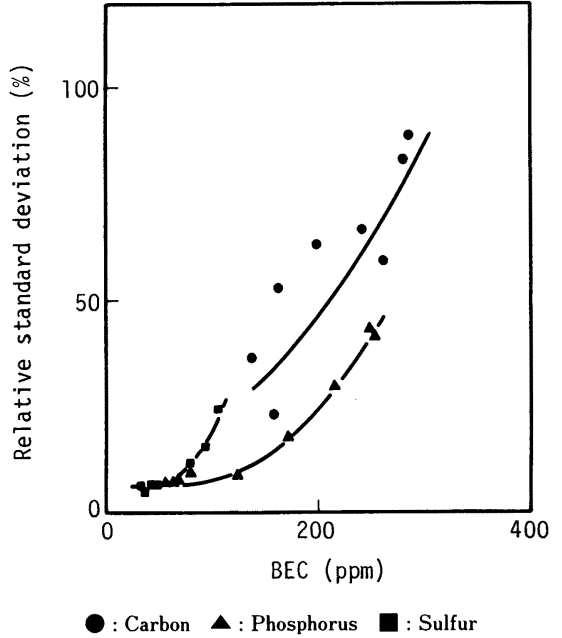

Fig. 9. Relationship between relative standard deviation at a concentration of $10 \mathrm{ppm}$ and background equivalent concentration.

果となった. また，これらの相対標準偏差とそれぞれの 設定時間における BEC の值との関係を Fig. 9 に示す. $\mathrm{BEC}$ の值が小さい条件では相対標準偏差も小さくなっ た.

ここで， $\mathrm{P}, \mathrm{S}$ に比較すると分析精度が劣る $\mathrm{C}$ につ いて, 放電䨌囲気中に $\mathrm{CO}_{2}$ ガスが存在すると, この存 在量の変動が分析精度を低下させると考え実験した. $\mathrm{Ar}$ ガス ${ }^{18) 19)}$ 中の $\mathrm{CO}_{2}$ ガスの含有量を変化させ, $\mathrm{C}$ の 発光スペクトル線強度の変化を調べた，純度 $99.9995 \%$ $\left(\mathrm{O}_{2}<0.2 \mathrm{ppm}, \mathrm{N}_{2}<3 \mathrm{ppm}, \mathrm{H}_{2}<1 \mathrm{ppm}, \mathrm{CO}_{2}<0.3\right.$ $\left.\mathrm{ppm}, \mathrm{CH}_{4}<0.5 \mathrm{ppm}\right)$ の $\mathrm{Ar} に 2 \mathrm{ppm}$ および $4 \mathrm{ppm} の$ 
$\mathrm{CO}_{2}$ を混入させたガスを用いた。この時のプロフィー ルおよび検量線を Fig. 10 および Fig. 11 に示す. Fig. 10 のプロフィールは時間分解測光を行わないときの データである. $\mathrm{Ar}$ ガスに $\mathrm{CO}_{2}$ ガスが含有されている 時（放電雾囲気に $\mathrm{CO}_{2}$ が存在すると）, $\mathrm{C}$ の発光強度 が高くなることがわかる. $\mathrm{CO}_{2} 2 \mathrm{ppm}$ を添加した場合, C $10 \mathrm{ppm}$ 試料は $99.9995 \% \mathrm{Ar}$ での検量線を用いると 時間分解測光を行わない時 $212 \mathrm{ppm}, 50 \mu \mathrm{s}$ での時間分 解測光を行った時 $276 \mathrm{ppm}$ と定量される. 発光分光分

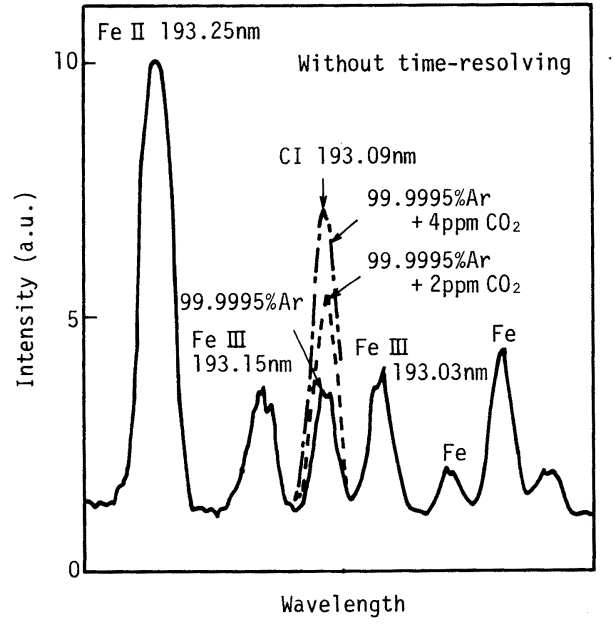

Fig. 10. Variation in C spectrum profile by adding carbondioxide into Ar gas.
析に用いられる $\mathrm{Ar}$ ガスには若干の $\mathrm{CO}_{2}$ あるいは $\mathrm{CH}_{4}$ ガスが含有されており，また，放電需囲気に空気 $\left(\mathrm{CO}_{2}\right.$ $300 \mathrm{ppm}$ 含有)が流入する.これらの $\mathrm{CO}_{2}$ ガスあるいは, 本実験では発光強度と濃度の関係は調べなかったが, $\mathrm{CH}_{4}$ 等の炭化水素ガスが $\mathrm{C}$ 分析の精度を劣化させる一 因になると考えられる.

\section{$3 \cdot 2$ 時間分解測光による近接線の影帮の減少}

発光分光分析における近接線の影響は一般には補正 式20)を用いて除かれている. 本研究では，時間分解測 光により近接線の影響を除くことを試みた。

(1)P 分析線における $\mathrm{Ni}$ の影響

PI $178.29 \mathrm{~nm}$ の分析線に影響を与える元素の一つに $\mathrm{Ni}$ がある ${ }^{17)}$. 時間分解測光の効果を $9 \% \mathrm{Ni}$ 鋼と炭素鋼 での $\mathrm{P}$ の検量線を比較することにより調べた．用いた 試料を Table 3, 結果を Fig. 12 に示す. 時間分解測光 を行わない場合は， $9 \% \mathrm{Ni}$ 鋼の検量線は炭素鋼の検量 線より高発光強度側にある，炭素鋼の検量線を基準検量

Table 3. Reference samples used for the experiment $(\%)$.

\begin{tabular}{ccccccccc}
\hline \multicolumn{2}{c}{ Sample No. } & $\mathrm{C}$ & $\mathrm{Si}$ & $\mathrm{Mn}$ & $\mathrm{P}$ & $\mathrm{S}$ & $\mathrm{Ni}$ & $\mathrm{Al}$ \\
\hline \multirow{3}{*}{$9 \% \mathrm{Ni}$} & 1 & 0.05 & 0.26 & 0.60 & 0.0002 & 0.0006 & 8.99 & 0.051 \\
steel & 2 & 0.02 & 0.21 & 0.25 & 0.0010 & 0.0013 & 8.48 & 0.026 \\
& 3 & 0.08 & 0.31 & 0.44 & 0.0021 & 0.0013 & 9.20 & 0.060 \\
& 4 & 0.12 & 0.16 & 0.93 & 0.0030 & 0.0015 & 9.47 & 0.044 \\
\hline \multirow{3}{*}{ Carbon } & 1 & 0.16 & 0.28 & 0.90 & 0.0012 & 0.0016 & - & 0.005 \\
steel & 2 & 0.15 & 0.29 & 0.91 & 0.0022 & 0.0036 & - & 0.009 \\
& 3 & 0.17 & 0.28 & 0.91 & 0.0033 & 0.0046 & - & 0.015 \\
& 4 & 0.16 & 0.29 & 0.90 & 0.0044 & 0.0056 & - & 0.041 \\
\hline
\end{tabular}

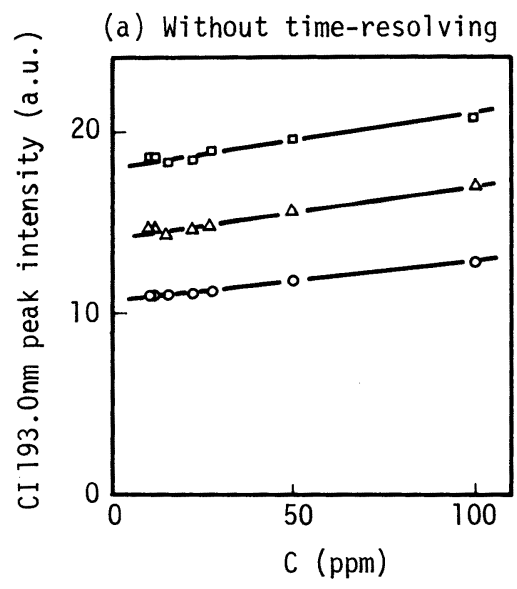

\section{(b) With time-resolving(50us)}

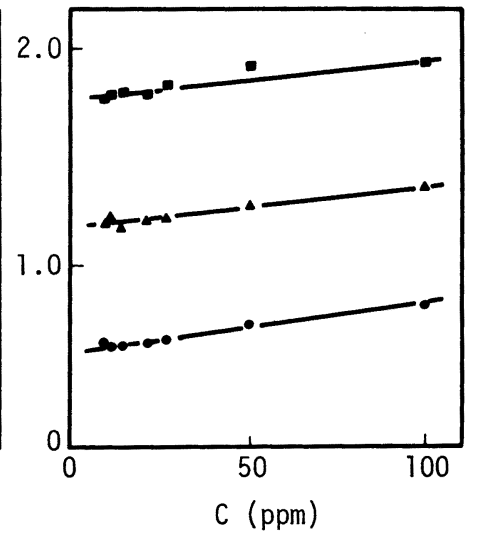

: $99.9995 \%$ purity $\mathrm{Ar} \Delta \boldsymbol{\Delta}: 99.9995 \%$ purity $\mathrm{Ar}+2 \mathrm{ppm} \mathrm{CO}_{2}$

$\square$ : $99.9995 \%$ purity $\mathrm{Ar}+4 \mathrm{ppm} \mathrm{CO}_{2}$

Fig. 11. Variation in working curve for carbon by adding carbondioxide into Ar gas as discharge atmosphere. 

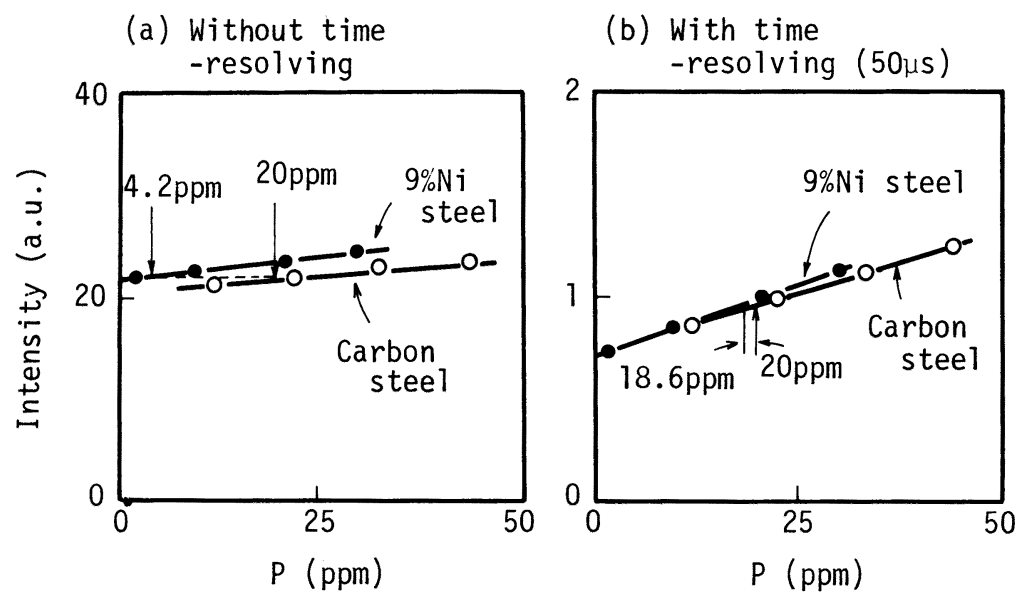

Fig. 12. Working curves for phosphorus in $9 \% \mathrm{Ni}$ and carbon steels with and without time-resolving technique.

線として, $9 \% \mathrm{Ni}$ 鋼の検量線の $\mathrm{P} 4.2 \mathrm{ppm}$ における光 強度での $\mathrm{P}$ 濃度を求めると $\mathrm{P} 20.0 \mathrm{ppm}$ となる. Ni $9 \%$ 当たり $\mathrm{P}$ は $15.8 \mathrm{ppm}$ 高く定量されることになる. $\mathrm{Ni}$ $1 \%$ 当たりに換算すると $\mathrm{P} 1.8 \mathrm{ppm}$ であり，共存元素 含有率 $1 \%$ 当たりの目的元素分析值に与える䛊差であ る影響係数 ${ }^{17) 20)}$ は $1.8 \times 10^{-4}$ となる.この值はこれ までに求められている值 $2 \times 10^{-4}$ 17) とおおむね一致 する．時間分解測光 $(50 \mu \mathrm{s})$ を行った時は $9 \% \mathrm{Ni}$ 鍓の 検量線と炭素鋼の検量線は，ほほ一致し，9\% Ni 鋼の 検量線で $18.6 \mathrm{ppm}$ における光強度を炭素鋼の検量線で 定量すると $20 \mathrm{ppm}$ となる．この時の $\mathrm{Ni}$ の $\mathrm{P}$ に対する 影響係数は $0.16 \times 10^{-4}$ であり，P に対する $\mathrm{Ni}$ の共存 元素の影響は時間分解測光により $1 / 11.3$ に減少した.

( 2 )S の分析における Mn の影響

$\mathrm{S}$ 分析の基準試料を Table 4 のように Mn 濃度 $0.50 ， 1.00$ ，および $1.50 \%$ の三水準において作製し， それぞれの $\mathrm{Mn}$ 濃度の水準における $\mathrm{S}$ の発光強度と $\mathrm{S}$ 濃度との関係を Fig. 13 のように求めた. Mn 1.00\%の 検量線を基準検量線として Mn 1.50\%の検量線上の $2.5 \mathrm{ppm}$ における $\mathrm{S}$ の発光強度から $\mathrm{S}$ を定量すると $10.0 \mathrm{ppm}$ となり $\mathrm{Mn}$ が $0.5 \%$ 高いと $7.5 \mathrm{ppm}, \mathrm{Mn} 1 \%$ 当たりに換算すると， $\mathrm{S}$ は $15 \mathrm{ppm}$ 高く定量される。

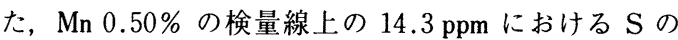
発光強度から Mn $1.00 \%$ の検量線を基準検量線として $\mathrm{S}$ を定量すると $10 \mathrm{ppm}$ となり，Mn 1\% 当たり 8.6 $\mathrm{ppm}$ 低く定量されることになる．時間分解測光を行わ ない時の Mnの SI $180.73 \mathrm{~nm}$ の分析線に対する影響係 数は $8.6 \times 10^{-4} \sim 15 \times 10^{-4}$ となり，これまで得られ
Table 4. Reference samples used for the experiment $(\%)$.

\begin{tabular}{cccccccc}
\hline \multicolumn{2}{c}{ Sample No. } & $\mathrm{C}$ & $\mathrm{Si}$ & $\mathrm{Mn}$ & $\mathrm{P}$ & $\mathrm{S}$ & $\mathrm{Al}$ \\
\hline \multirow{3}{*}{$0.5 \% \mathrm{Mn}$} & 1 & 0.0008 & 0.28 & 0.52 & 0.001 & 0.0004 & 0.001 \\
& 2 & 0.0005 & 0.27 & 0.51 & 0.001 & 0.0005 & 0.001 \\
& 3 & 0.0005 & 0.29 & 0.54 & 0.001 & 0.0008 & 0.001 \\
& 4 & 0.0007 & 0.28 & 0.51 & 0.001 & 0.0013 & 0.001 \\
\hline \multirow{3}{*}{$1.0 \% \mathrm{Mn} n$} & 1 & 0.0007 & 0.28 & 1.00 & 0.001 & 0.0003 & 0.001 \\
& 3 & 0.0007 & 0.28 & 1.02 & 0.001 & 0.0006 & 0.001 \\
& 4 & 0.0007 & 0.29 & 1.05 & 0.002 & 0.0012 & 0.001 \\
$1.5 \% \mathrm{Mn}$ & 0.0006 & 0.30 & 1.04 & 0.001 & 0.0015 & 0.001 \\
& 1 & 0.0007 & 0.27 & 1.50 & 0.001 & 0.0005 & 0.001 \\
& 2 & 0.0006 & 0.29 & 1.57 & 0.001 & 0.0008 & 0.001 \\
& 4 & 0.0006 & 0.29 & 1.55 & 0.001 & 0.0012 & 0.001 \\
& 0.0010 & 0.28 & 1.51 & 0.001 & 0.0020 & 0.001 \\
\hline
\end{tabular}

ている $13 \times 10^{-4}$ 17) とほぼ一致している. 同様の方法 で求めた時間分解測光（設定時間 $50 \mu \mathrm{s}$ ）を行った時の 影響係数は $0.2 \times 10^{-4} \sim 5.8 \times 10^{-4}$ であり，時間分解 測光により $\mathrm{S}$ に対する $\mathrm{Mn}$ の影響が減少することがわ かる。

$\mathrm{P}$ に対する $\mathrm{Ni}, \mathrm{S}$ に対する $\mathrm{Mn}$ のいずれの場合も分 析線は中性線であり, 共存元素のイオン線が近接線とし て存在している ${ }^{17)}$. スパーク放電の初期にはイオン線 の強度が強いため, 時間分解測光を行わない場合には共 存元素の影響が大きく現れた．放電初期の発光強度を除 いた放電開始後 $50 \mu \mathrm{s}$ 以降での時間分解測光を行うと, 共存元素のイオン線の強度はほとんど減衰するため共存 元素の影響が減少する結果となった．共存元素の影響は 近接線の影響とマトリックス効果にわけられる ${ }^{17)}$. 時 間分解測光により影響を軽隇できるのは近接線の影響の 場合である. 分析線と共存元素の近接線の一スパーク放 電での時間-光強度曲線に差がある場合にその差を利用 
(a) Without time-resolving

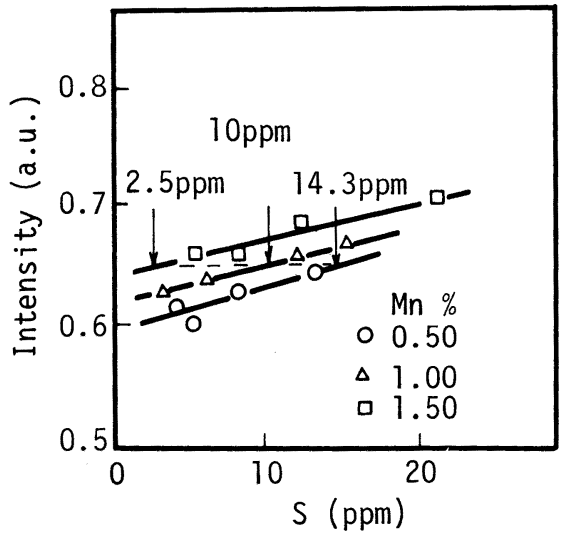

(b) With time-resolving (50us)

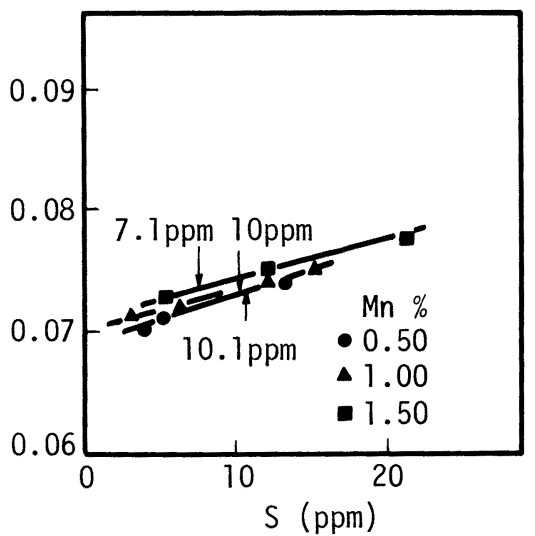

Fig. 13. Analytical curves for sulfur in steels containing various amount of manganese with and without time-resolving technique.

して共存元素の影響を除くことができる．基本的には分 析線が中性線, 近接線がイオン線の場合は放電の後期の 発光強度を測定することにより, 分析線がイオン線, 近 接線が中性線の場合は放電の初期の発光強度を測定する ことにより，近接線の影響を除くことができると考えら れる7). しかし，中性線においてアフターグローの長い 元素と短い元素があること, 近接線の影響とマトリック 又効果による影響が複合して現れる場合がある7)こと等 から時間分解測光によりどの程度まで影響を除けるかは それぞれの場合において実験する必要があると考えられ る.

\section{4. 結言}

（1）C，P，Sいずれの場合も時間分解測光により, $B E C$ の值は低下し, 高精度の分析が行えた. $10 \mathrm{ppm}$ 濃 度に扔ける標準偏差は時間分解測光法を用いない時, $\mathrm{C}$ $8.7 \mathrm{ppm}, \mathrm{P} 4.2 \mathrm{ppm}, \mathrm{S} 2.4 \mathrm{ppm}$ であったのに対し，時 間分解測光を行った場合には C $2.3 \mathrm{ppm}$ (放電開始から $40 \mu \mathrm{s}$ 以降の全強度測定において最も良い結果が得られ た. 以下同じ), P $0.8 \mathrm{ppm}$ ( 40 あるいは $50 \mu \mathrm{s}), \mathrm{S} 0.5$ ppm $(50 \mu \mathrm{s})$ であった.

(2)時間分解測光により $\mathrm{P}$ に対する $\mathrm{Ni} ， \mathrm{~S}$ に対する $\mathrm{Mn}$ の共存元素の近接線の影響を除くことができた， Ni が P の分析におよほす影響量は Ni 1\% 当たり，時間分 解測光法を用いない時の $1.8 \mathrm{ppm}$ から時間分解測光法 を用いた時の $0.16 \mathrm{ppm}$ に減少した。 また, $\mathrm{Mn}$ が $\mathrm{S}$ の 分析におよぼす影響量も Mn 1\% 当たり 8.6〜 15 ppm から時間分解測光により $0.2 \sim 5.8 \mathrm{ppm}$ に隇少した.

\section{文献}

1 ) 井樋田睦: 第 61.62 回西山記念技術講座（日本鉄鋼協会 編) (1979), p. 71

2 ) 井桶田睦, 佐藤利光: 日本鉄鋼業における分析技術（日本 鉄鋼協会共同研究会鉄鋼分析部会編）（1982）, p. 347

3 ) 奥山祐治, 浅沼吉郎, 仁部晴美, 菊池統一: 材料とプロセ ス, 2 (1989), p. 532

4 ) ASTM Standard E116 (1981)

5 ) 原子スペクトル分析（日本分析化学会編）（1979）, p. 131, p. 347 [丸善]

6 ) P. W. J. M. Boumans: Analytical Emission Spectroscopy, ed. by $E$. L. Grove (1972), p. 82 [Marcel Dekker New York]

7 ) H. Goto, S. IKEDA, $A$. SAITo and M. SuZuKI: Fresenius Z. Anal. Chem., 220 (1966), p. 95

8 ) K. HiroKaWA and H. GoTo: Spectrochim. Acta, 25B (1970), p. 419

9 ) A. BARdocZ: Appl. Spectrosc., 11 (1957), p. 167

10) $K$. Laqua and W. D. Hagenah: Spectrochim. Acta, 18 (1962), p. 183

11) $R$. Diermeier and $H$. Krempl: Spectrochim. Acta, 25B (1970), p. 69

12) R. J. Klueppel, D. M. Coleman, J. W. Hosch and J. $P$. WALTER: Spectrochim. Acta, 33B (1978), p. 741

13) J. P. Walters and S. A. GoldStein: Spectrochim. Acta, 39B (1984), p. 693

14）福井 勲, 今村直樹: 第 21 回応用スペクトロメトリー 東京討論会講演要旨集 $(1985)$, p. 37 [応用物理学会]

15）小野寺政昭, 佐伯正夫, 西坂孝一, 坂田忠義, 小野準一, 福井 勲, 今村直樹: 鉄と鋼, 60 (1974), p. 2002

16）小野準一, 福井 勲, 今村直樹: 島津評論, 35 (1978), p. 15

17) JIS G1253 (1983)

18) JIS Z2611 (1977)

19) JIS K1105 (1984)

20) ASTM Standard E158 (1983) 